\title{
The Temporal and Chroonological Distance in Translations of Holy Writ: to Preserve or to Eliminate?
}

\author{
Georgy T. Khukhuni ${ }^{1}$, Irina I. Valuitseva ${ }^{2}$, Anna A. Osipova ${ }^{3}$ \\ ${ }^{1,2}$ Moscow State Region University (MGOU) \\ Vera Voloshinova str. Bd. 24, Mytishchi, Moscow Region, Russian Federation, 141014 \\ ${ }^{3}$ Moscow State Pedagogical University (MPGU) \\ Malaya Pirogovskaya str. Bd. 1/1, Moscow, Russian Federation, 119991 \\ ${ }^{1}$ khukhuni@mail.ru
}

The present paper deals with some cases of the modernization of the Bible texts, especially created in the second part of the $20^{\text {th }}$ and the beginning of the $21^{\text {st }}$ centuries (although the elements of the latter may be found in earlier versions including those with the unofficial status of "national Bibles"). The expansion of modernization is usually connected with E. Nida`s theory of the dynamic / functional equivalence; at the same moment its direct influence is obvious enough. The actuality of the theme for the theory and practice of translation is caused by the following factors: 1. the richness and variety of the Bible translations, the history of which counts more than two thousand ears; 2 . the necessity to take into account the referential part of the text on one hand, and its pragmatic and appellative functions on the other; that may lead to the collision between them when the translator has to choose the strategy and tactics of his work; 3. the acceptance of the text as "inspired by God" among the believers, that may provoke a negative relation towards some moments, which are treated as the divergence from the source text or even its distortion. The paper is based on the representative sample taken from Bible translations (both "traditional" and modern) in Russian, English and German. The corresponding variants, as well as their estimation in special and popular works are analyzed. The authors give an attempt to define some features that give the possibility to treat the text as modernized one. Although the said method is used quite often as the means to reach the adequacy of translation, the question of its limits is controversial enough.

Key words: original, translation, Bible, pragmatic, modernization, adequacy, distortion

\section{Article history:}

Received: 01.06.2019

Accepted: 15.09.2019

\section{For citation:}

Khukhuni, G.T., Valuitseva, I.I. \& Osipova, A.A. (2020). The Temporal and Chroonological Distance in Translations of Holy Writ: to Preserve or to Eliminate? RUDN Journal of Language Studies, Semiotics and Semantics, 11(1), 22 - 35 . doi: 10.22363/2313-2299-2020-11-1-22-35

(C) Хухуни Г.Т., Валуйцева И.И., Осипова А.А., 2020. 


\title{
«Пафос дистанции» при передаче Священного Писания: воспроизводить или снимать?
}

\author{
Г.Т. Хухуни, ${ }^{1}$ И.И. Валуйцева, ${ }^{2}$ А.А. Осипова ${ }^{3}$ \\ ${ }^{1,2}$ Московский государственный областной университет (МГОУ) \\ ул. Веры Волошиной, 24, Мытищи, Российская Федеращия, 141014 \\ ${ }^{3}$ Московский педагогический государственный университет \\ ул. Малая Пироговская, 1, строение 1, Москва, Российская Федеращия, 119991 \\ ${ }^{1}$ khukhuni@mail.ru
}

\begin{abstract}
В статье рассматриваются некоторые случаи модернизации текстов Священного Писания в переводах Библии, выполненных по преимуществу во второй половине XX - начале XXI в. $\mathrm{C}$ ее элементами можно столкнуться и в более ранних версиях, в том числе имеющих неофициальный статус «национальных Библий» Модернизация часто связывается с теорией динамической (позже функциональной) эквивалентности, разработанной в трудах Ю. Найды и его последователей; однако не всегда ее влияние представляется очевидным. Актуальность темы исследования для теории и практики межъязыковой передачи обуславливается рядом моментов: 1. богатой и разнообразной историей переводов библейских книг, насчитывающей более двух тысячелетий; 2. необходимостью учитывать как собственно референциальную, так и прагматически-апеллятивную функцию Священного Писания, которые нередко приводят к коллизиям при выборе стратегии и тактики перевода; 3. статусом «богодухновенности» в глазах верующих, обуславливающим порой резкую реакцию на изменения, воспринимаемые как отклонение или даже искажение оригинала. Материалом исследования послужил ряд переводов Библии (как традиционных, так и современных) на английском, немецком и русском языках, указанных в списке источников. Был проанализирован массив примеров перевода, рассмотрены предлагавшиеся в них решения, а также отклики, которые эти переводы вызвали в научных и публицистических трудах. Предпринята попытка представить основные признаки, позволяющие говорить о модернизации текста как в собственно языковом, так и в идейносодержательном отношении. Отмечается, что хотя модернизация нередко применяется как средство достижения адекватности перевода, однако вопрос о ее допустимых границах является дискуссионным.
\end{abstract}

Ключевые слова: оригинал, перевод, Библия, модернизация, прагматический, адекватность, искажение

\section{История статьи:}

Дата поступления: 01.06.2019

Дата приема в печать: 15.09.2019

\section{Для цитирования:}

Хухуни Г.Т., Валуйцева И.И., Осипова А.А. «Пафос дистанции» при передаче священного писания: воспроизводить или снимать // Вестник Российского университета дружбы народов. Серия: Теория языка. Семиотика. Семантика. 2020. Т. 11. no 1. С. 22-35. doi: 10.22363/23132299-2020-11-1-22-35

\section{Introduction}

Among the multiple paradoxes accompanying cultural development during the latest century in the countries which belong to the so called "western civilization", one needs to remark that, on the one hand, it's characterized by a gaining strength secularization process. On the other hand, during this very period the activity in Bible 
translation greatly enlarged its scope — both in creating the versions of the Holy Writ using the idioms never used before, and translating the Holy Writ into languages having a century-long tradition. Primarily speaking of the English language, we'd mention the number of the Holy Writ translations using various provisions, which might number in a few thousands.

The period mentioned is also characterized by a substantial development of theoretical studies devoted to various aspects of Biblical translation and methods to reproduce the Holy Writ in the past and at present. Those are classical works by E. Nida and his colleagues ([1], [2], [3]), and the influence of those ones has extravagated the farthest limits of the topic issues. Among the other studies that gained reputation, including Russia, one'd name J. Bickman and J. Callow [4], B. Metzger [5], I. Chatzitheodorou [6], M. Huaizhou [7] and a number of others (more complete information on might find in the monography by A.S. Desnitskij [8]).

As is believed, such a thorough attention to the Holy Writ translations as well involving the authors who don't belong to any Christian confession or generally abiding to atheistic ideology, is stipulated by a number of reasons:

1. Abundant and broad-ranging history of biblical books translations developing for over two millennia;

2. The necessity to take into consideration both referential proper and pragmaticand-appellative Holy Writ functions which often leads to some collisions while choosing strategies and tactics of translation;

3. The status of " the Holy Inspiration" among the believers, sometimes determining a rather acute reaction on these and that moments which are perceived as deflections or even distortion of the original source.

In those situations when the given culture already disposes the Holy Writ translations, and among those there might be some having the non-official status of "national Bibles" as Luther Bible in Germany, King James Bible in the English-speaking world or - with a few remarks - the Synodic translation in Russia (more details find in [9]), there comes the question to what extent new translations are in demand, and what their specifics might be. More often (although not always) such demand is viewed as the means to approximate the text to a contemporary reader, id est to modernize it, to a certain extent. Due to the article limits, let's give a few but most typical examples of modernizations found out in the texts we'd analyzed.

\section{The Notion of Translational Modernization}

While discussing the questions of translational modernization, it's oftentimes correlated with another dichotomy largely used in the works on translation studies and well-known as foreignization vs. domestication. In modern science, the notions are mainly connected with the works by L. Venutti [10], [11], those the phenomena mentioned were covered by classic authors, and L. Venutti himself mentions it. Actually, those strategies overlap rather frequently: as a rule, modernization used to "domesticate" the rendered text dabbling phenomena and realia of a reader's environment although they have certain differences. If domestication could be applied both to ancient texts and in course of translating to modern authors, modernization is a phenomenon specially characteristic of a diachronic (chronological) translation while us- 
ing the V.S. Vinogradov's words, "timely distance between the creation of the original and its translation becomes substantial, the timelines of the source and target languages are no longer correlating, and extralinguistic features of corresponding epochs differ radically" [12. P. 139].

The method of modernization is often used in original works - in those cases when the appeal to history serves an author as a means to cover hot present-day issues. In particular, it was used by Bernard Shaw ("Caesar and Cleopatra", "St. Joanna"), Lion Feuchtwanger (the trilogy of Judaic War novels is the most famous example), Robert Graves (the dilogy written in the name of Claudius, the Roman Emperor). Modernization was observed in academic studies as well: thus, characterizing the works by German colleagues in the field of Classical Antiquity history one of the Russian scholars told that their works contained "regular use of $<\ldots>$ terms belonging to modern language, e.g., ,,vice-king“, ,governor“, ,,adjutant-general“, „Reich mareschal", etc.", when one has to consider "traditions of both German historiography where modernization of Classical Antiquity came to stay since the times of $\mathrm{T}$. Mommsen (mid-19th century) and Russian translations conserving this orientation of German Antiquity studies“" [13. P. 3].

V.N. Komissarov, with a little exaggeration of the situation, defined modernizing translation as a kind of strategy of "historic personalities to 'work overtime', 'exercise economy regime', 'carry out irrelevant personnel policy', 'solve problematic issues in off-work hours", etc. <... . If the source text reads about Achilles's arrows, in the modernized translation their place may take missiles from Cape Canaveral" [14. P. 149]. Such examples one may also come across in biblical translations made from the modernization perspective (a few samples of those are to follow). Still, in this case, besides "general translational" intention to reflect on the extent of such a strategy be approved and implemented, or if it leads to actual arbitrary decision of a translator in relation to the original source text, there come into operation a few specific features of a sacral text, in particular.

\section{Holy Writ: the Topic of Translation Profile}

The history of literature discloses the cases when this or that translated text (target text) was originally perceived by a hosting culture of a certain epoch as an epitome, a model text, having, according to B. Pasternak, "the right of final authority as that of the source text" (see in: [15. P.161]). In the context of proper literary masterpieces, the presence of a suchlike version doesn't cause an active protest in respect to attempts to elaborate a new translation. For example, the author of the above-quoted words addressed them to the translation of "King Lear" by A.V. Druzhinin, which didn't prevent B. Pasternak from making a translation of his own. As to the Holy Writ, the situation seems different: such attempts might be understood by a significant number of believers not just as a "translator's audacity", but as a "sacrilegious offence upon the buttress", even in case a text is not modernized, but on the contrary, is acquitted of mistakes and inaccuracy. In one of his works, E. Nida gave a typical example of a Bible translator into one of the Western African languages, who later on got a linguistic training, and on finding in his own translation a number of mistakes, wanted to correct them, but was rejected due to the fact that no one has a right to 
change the Word of the Lord, "< $<>$ after one translator in West Africa had completed the translation and publication of the Bible in one of the important trade languages of the area, he decided to take some courses in linguistics at a leading university in England while he was on furlough. He soon realized how many mistakes he had made in his earlier work, and so after returning to the field, he asked for permission to undertake an important revision. But his colleagues insisted that he had no right to change the Word of the Lord" [16]. In other words, there occurs the authentication of the text content and the wording which is traditional in the given culture. Assigning to a translation "the right to be as authoritative as the original source text", one starts to assume not only metaphorically, but literally as it happened with Latin version of Biblia Vulgata which for many centuries, was treated by the Roman Catholic Church not just as equal, but as preponderate over Hebrew and Greek texts of the Old and New Testaments.

Moreover, alongside with the intention of "conservation" of this or that version being authoritative for a given community, there came the understanding that ignoring processes of linguocultural evolution could lead to a significant weakening of pragmatic effect and appellative function of the Holy Writ (that is, to devaluation of a great extent the reason to create translations), and it could also distort the communicative aspect which means difficulty in understanding the content itself. Argumentation of a demand of new versions of the Bible started more often with emphasizing this fact which already vividly revealed itself in the preface to the first Russian version of the New Testament created over two hundred years ago, «<..> meanwhile the bookish language is permanently conserved for many ages, the oral language of a nation is undergoing many changers during a single century, and what aws written for a few centuries in this native language nowadays is less understood without special language studies of this language in its ancient state. This fact opens unhampered use and interpretation of the Word of the Lord and the need not only to translate the Holy Writ into native language, but from time to time, using this language to renew the translation according to the statues of this language in its national use" [17]. However, from the middle of the $20^{\text {th }}$ century, it was not just proper language aspect (though it was not forgotten), but the pragmatic one moved to the foreground, and many works of that period clearly demonstrated the trend.

\section{From "The Holy Kiss" to "The Cordial Handshake"}

As was said, contemporary translation modernism in relation to biblical translation used to date back to the concept of E. Nida (see the title of one of the articles devoted to him [18]). We'd remark that E. Nida speaking himself about those versions of the Holy Writ of his time which to the fullest extent reflect the intention to achieve the equivalent effect, specially emphasized the New Testament translation made by British biblical scholar J.B. Phillips. The most spectacular example of the "natural projection" applied by him, he calls the substitution of the invitation of the original source text to "exchange greetings with a Holy Kiss" instead of exchanging of "a Cordial Handshake": "One of the modern English translations, which, perhaps, more than any other, seeks for equivalent effect is J.B. Philips's rendering of the New Tes- 
tament. In Romans 16:16 he quite naturally translates 'greet one another with a holy kiss' as 'give one another a hearty handshake all around"' [1. P. 159-160].

We have already written about the activity of J.B. Phillips [19]. So we'd confine ourselves to indicate the following. Firstly, in course of his following work, he had a little reduced the degree of "naturalness" of his translation, though without sacrifice of this very example. Secondly, the biblical translations which observed E. Nida's recommendations (English version of Good News Bible / Good News Translation, German one of Gute Nachricht Bibel), the change introduced by J.B. Phillips was not accepted as to the example of the abstract from the Second Epistle to Corinthians of Paul the Apostle: Greet one another with the kiss of peace / Grüßt einander mit dem Friedenskuss [29], [30].

Neither J.B. Phillips, nor E. Nida, or their followers in various countries avoided sharp criticism (see: [21]) of translation principles put forward by them. Moreover, their opponents often compared their translations with classical "national" translations contrasting the "vulgar" vernacular" of the first to the "grand style thoroughness" of the second ones. In its turn, according to E. Nida, it made their proponents of "the new point of view" (the new focus) doubt that "nimbus of infallibility" and "unsurpassed ideal" which is assigned by the conservatives to traditional versions. The most vivid form of this approach revealed itself in the study of a scholar and writer C.S. Lewis well-known in this country mainly as the author of "The Chronicles of Narnia". His arguments were rather typical and later on continually repeated. On the one hand, he specified that the New Testament original language was not at all the model of "grand style", and so much cherished "sacrality" and "grandness" of classical translations often turned into complete incomprehensibility. On the other hand, and what is of interest to us, C.S. Lewis stated that beauty and solemnity of language and style of the mentioned King James Bible, in many cases demonstrate its main imperfections, "drowsing" the reader and blunting his emotional reaction, " $<\ldots>$ though it may seem a sour paradox — we must sometimes get away from the Authorized Version, if for no other reason, simply because it is so beautiful and so solemn. Beauty exalts, but beauty also lulls. Early associations endear but they also confuse. Through that beautiful solemnity the transporting or horrifying realities of which the book tells may come to us blunted and disarmed and we may only sigh with tranquil veneration when we ought to be burning with shame or struck dumb with terror or carried out of ourselves by ravishing throes and adoration" [22].

"Modernistic" revision of the Bible cross-language transfer principles was also realized by other theorists and translators, and wasn't directly connected with the works of J. Phillips and E. Nida. One used to be reminded of the representatives of scopos-theory which was started with the book by K. Reiß and H. Vermeer [23]. This concept is discussed in the work of A.S. Desnitskij [8. P. 85-99].

In our opinion, special attention should be paid to the "modernized" Holy Writ version by representatives of Protestant denominations made in the USA practically simultaneously with the Good News Bible. This so called New International Version (NIV) [31] is often positioned as the most popular on the American continent. It considered to be initialized by Howard Long, engineer by trade. As far as we know, neither he, nor his successors declare their connection with the work of J. Phillips or E. 
Nida's concept. However, the explanation of the reasons why it appeared, resemble those which were quoted in the C.S. Lewes's statement above — the incomprehensibility of the classical text of the English Bible for the present day reader is emphasized, "Long was a lifelong devotee of the King James Version, but when he shared it with his friends he was distressed to find that it just didn't connect. Long saw the need for a translation that captured the truths he loved in the language that his contemporaries spoke" [24]. J. Phillips reflected on how during the bombing, he was reading to them King James Bible trying to encourage young people sheltering in the bomb shelter. Both in content and form, the argumentation reminds us of the fragment cited above: " $<\ldots>$ when $<\ldots>$ I attempted to while the time away by reading to them from the Authorized Version, quite honestly they couldn't make any sense of it at all"' [20. P. 153].

Authors of modernized versions frequently tend to present their own activity not like estrangement of the established tradition, but, on the contrary, as its further development meeting the background set by the "father-founders". There are many examples of the kind, therefore we confine to the reference to the German version of Hoffnung für alle) [32], not quite well-known in this country. It is published starting from the 80 s of the $20^{\text {th }}$ century and was positioned as Die Bibel, die deine Sprache spricht (the Bible speaking its own language). As the other "modernized" versions that translation didn't avoid the blame of the authors in pursuing "comprehensibility", let themselves more liberty to transform the original source. It's typical that to maintain their attitude, the authors of the target text refer not only to fact of a translation be based on the modern achievements of linguistics and methods of translation («folgt $<\ldots>$ modernen sprachwissenschaftlichen Erkenntnissen und Übersetzungmethoden»), but call for help to the author of classical German Bible - Martin Luther. They quote the Luther's words about the necessity in course of translation, "to look into the mouth of people", as it should not just render the content of the original, but be understandable, possess natural and fluent sounding making the same impression on a reader that the original source text produced in its own time (compare with "reaction of an addressee" of E. Nida's concept), "“Man muss den Leuten aufs Mund schauen!" — so hat Martin Luther seinerzeit anschaulich beschrieben, wie er bei seiner Bibelübersetzung vorging. Bis heute ist sein Motto für jede gute Übersetzung wegweisend geblieben. Eine gelungene Übersetzung soll nicht nur die Botschaft des Originaltextes zuverlässig wiedergeben, sie muss auch verständlich sein, natürlich und lebendig klingen so wie wir uns in unserer Sprache ausdrücken. Kurzum: sie soll auf ihre Leser möglichst die gleiche Wirkung haben, wie sie das Original auf die damaligen Leser hatte!» [32. P. XXVIII].

If to speak about the most vivid elements of modernization, even for those readers who are not really mature in historic realia, the most obvious thing is that the biblical personalities use such metrology which date back not to centuries, but to millennia after the original source text was created. Thus, in "Bible for everyone" Noah receives form the God the following instruction on building the Ark (Gen. 6:15) (the titles of The Holy Books and persons names are given according the Russian Synodic translation): Es muss 150 Meter lang, 25 Meter breit und 15 Meter hoch sein; and the hair of King David Abishalom are said to be (2 Kings 14:26): Sie wogen mehr als 
zwei Kilogramm. In some versions using similar modernization the national and cultural specifics is considered concerning the audience to which the text appeals. Thus, for the countries which adopted metrology in meters, kilos, etc., this very system is used, but in the version of Good News Translation addressed to a British reader [29], traditional metrology for this country and culture are used: Make it 450 feet long, 75 feet wide, and 45 feet high; It would weigh about five pounds $<\ldots$. .

Special attention should be paid to "gender modernization" of the Holy Writ text which is treated in terms of political correctness and feministic stand (see: [25]). Still, for now the issue is beyond the article.

\section{Modernizm of Translation and Russian Biblical Translations}

The question of making new Holy Writ translations in the area of this country was already asked by several authors in the beginning of the last century, but the practical realization of it took place at the turn of 19-20th centuries when a few versions of the Holy Writ came into being (their review one can find in the above mentioned monography of A.S. Desnitskij [8. P. 221-259]). They couldn't but reflect those trends which were seen in this sphere abroad. However, modernizing trends of the versions existing at present reveal themselves in lesser degree. If to come back to the above given examples concerning metrology features, the most well-known Holy Writ translations of the latest decade belongs to the Russian Biblical Society [33] and Zaoksky Theological Adventist Academy [34]; it contains the same units as in Synodic translation and The Church Slavonic Elizabeth Bible. In the first text one reads, "Пусть он будет в длину триста локтей, в иирину пятьдесят, а в высоту тридиать // вес сбритых волос составлял двести <..> шекелей; во второй: $<\ldots>$ длина его была триста локтей, ширина — пятьдесят, а высота тридиать // и бывало в них двести шекелей веса <... >" (lit.: Let it be three hundred cubits in length, fifty in width, and in height - thirty \ the weight of shaved hair makes two hundred $<\ldots>$ shekels of weight $<\ldots>$ ) (in the second example of both Synodic translation and Church Slavonic text, the form сиклей/ sekels is used). The Eastern (Central Asian) translation [35] meant for readers practicing Islam is an exception and follows "modernizers". This translation also contains metrological units modernization, «<..> ковчег должен быть сто тридиать пять метров в длину, двадиать два с половиной метра в иирину и тринадцать с половиной метров в выссоту // < ..> весили они около двух с половиной килограммов». (lit.: ... reliquary had to be one hundred and thirty five meters long, twenty two and a half meter wide and thirty and a half meters high // ... they weighed about two and a half kilos). However, there's a remark précising that the original text contains cubits and shekels. At that, to characterize this translation, one has to consider reasonably that although written in Russian, it could be just conventionally subsumed to proper Russian linguocultural tradition for which is still true the remark of K.I. Chukovskij (though for understandable reasons, he didn't mention Holy Writ translations), "Generally speaking, modern theory and practice of literary translation rejects free-and-easy treatment of national colour of verses, novellas and novels translated" [26. P.148].

The most vivid national and cultural specifics of the Russian tradition conserved to render historic realia reveals itself in the discussion on the New Testament transla- 
tion ("Glad Tidings") by V.N. Kuznetsova which was edited and included in the Bible of Russian Biblical Society. A lot of critical remarks volunteered against it, in the first place, concerning language and style. But the truth demands to admit that dramatic realia of "modernization" are not found in the text in majority of cases. In some cases historical colour is preserved even more strictly than in the Synodic translation. Thus, in the "Acts of the Apostles", the Synodic translation сотнику из полка // regiment mugwump correlates with центурион римской когорты //centurion of the Roman cohort (10: 1), воеводам - nреторы // waywode - praetors (16: 20), mblсяченачальнику полка - трибун когорты // regiment leader of thousand - cohort tribune (21: 31), правителю — прокуратор // governor — procurator (25: 12), etc.

We'd also like to remark that in course of cross-linguistic transfer, the notion of modernization itself might need more accuracy. It's worth mentioning the debate on the published in the beginning of the $20^{\text {th }}$ century about initial public offering of the Gospel of St. Matthew, made by Bishop Cassian, who lived and worked abroad (S.S. Bezobrazov). One of the renowned national Russian scholars of the Bible, A.I. Ivanov reacted to the work with rather sharp critical review. In this review, he reproached the author of translation to have used Russian word верста (lit.: verst) (Mtt. 5: 41) to render the Greek $\mu i \lambda ı o v$. The Synodic translation took after the Church Slavonic text the lexeme nonpume (lit.: course, stage). As A.I. Ivanov said, "Such modernization is hardly relevant be applied to Holy Writs, and if to bring to the end, in this case more modern term would be “километр (kilometer)"» [27]. Judging further the history of Bishop Cassian translation, the reproach against версma seemed convincing to its author. In the full version of the New Testament published in 1970 by British and Foreign Biblical Society, the abstract mentioned looks like that, "And who will make you walk with him a thousand steps, walk with him two (thousands)"'[36]. However, just the use of the word верста doesn't mean modernization, but rather domestication of the text, The Brockhaus and Efron Encyclopedic Dictionary (the end of the $19^{\text {th }}$ century) gives the evidence, "Versta (verst), or poprische (wayward) - a Russian road measure mentioned in the travel of hegumen Daniil" [28]. If to take into consideration that the "Travel of hegumen Daniil" dates back to the beginning of the $17^{\text {th }}$ century, the "modernism" of версmbl in the Holy Writ translation of the mid-20 would seem relativistic. Notably, the given lexeme was already used in the given context at the start of the $19^{\text {th }}$ century by translators of the New Testament of the Russian Biblical Society (И кто понудит тебя пройти с ним одну версту, иди с ним двеAnd who could make you walk with him one verst, walk two with him [37]), and at present authors of the Zaokskaya Bible version got back to it, though the expedience of such decision looks like a disputable one.

\section{Conclusion}

The question of compatibility of using modernization elements in course of diachronic chronological translation - and if "yes", to what extent, belongs to the so called "eternal questions" and the practice of cross-language transfer, and in the nearest future it could hardly get a univocal simple solution especially concerning sacred text. As a rule, the use of modernization is approved through achieving the adequacy of translation that means a translation "to satisfy $<\ldots>$ first of all, the set pragmatic task" 
[14. P. 152]; still, it's impossible to overdo the gap separating source and target texts. In other words, modernizing approach is ultimately based on the following principle: in translation, pragmatics is primary, and reference is secondary. As the example of the article to review modern versions of Holy Writ translations, at present, the above mentioned point of view could be recognized as a dominant in many foreign translations of the Bible. However, its absolutization could lead to the results which in the opinion of a greater part of reading audience seems to be a kind of burlesque (like the example of using by its characters metrology and weight measures in kilos), and this should be taken in account to elaborate strategies of sacral text translation.

\section{References}

1. Nida, Eugene. A. (1964). Toward a Science of Translation. Leiden: Brill.

2. Nida, Eugene. A. \& Taber, Ch. R. (1982). The Theory and Practice of Translating. Leiden: Brill.

3. Waard, J., Nida, Eu.A. (1986). From One Language to Another: Functional Equivalence in Bible Translation. Thomas Nelson Inc.

4. Bickman, J. \& Callow, J. (1974). Translating the Word of God: With Scripture and Topical Indexes. Zondervan.

5. Metzger, Bruce M. (1993) Persistent Problems Confronting Bible Translators. Bibliotheca Sacra 150 (July-September 1993).pp. 273-284.

6. Chatzitheodorou, Ilias (2001). Problems of Bible Translation, Translation Journal. 5(4). October 2001. URL: https://www.translationjournal.net/journal/18bible.htm (accessed: 08.12.2018).

7. Huaizhou, Mao. (2012). Commentary on Nida vs. Chomsky's Translation Theories, Theory and Practice in Language Studies, 2(6), June 2012, 1285-1290.

8. Desnitskii, Andrei.S. (2015). Modern Biblical Translation. Theory and Methodology. Moscow: PSTGU Publishing House. (In Russ).

9. Snigirev, Rostislav. National Bibles and the Problem of the Synodal Translation Emendation. Theology.ru. Scientific Theological Portal. URL: http://www.bogoslov.ru/text/404972.html (accessed: 08.06.2017). (In Russ).

10. Venuti, Lawrence M. (1999). The Scandals of Translation: Towards an Ethics of Difference. Routledge.

11. Venuti, Lawrence M. (2001). Strategies of Translation In Routledge Encyclopedia of Translation Studies. London \& New-York. Routledge. pp. 240-244.

12. Vinogradov, V.S. (2001). Introduction in Tranalatology (General and Lexical Problems). Moscow: Institute of General and Secondary Education. (In Russ).

13. Frolov, E.D. (1982). History of the Hellenism in the Biographies of its Creators. In: Betson, G. The rulers of the Hellenistic Period. Moscow: Nauka. pp. 3-26. (In Russ).

14. Komissarov, V.N. (2000). Modern Translatology. Course of Lectures. Moscow: ETS Publishing House. (In Russ).

15. Levin, Y.D. (1885) Russian Translators of the $19^{\text {th }}$ Century and the Development of the Literary Translation. Leningrad: Nauka. (In Russ).

16. Nida, E.A. (1994). The Sociolinguistics of Translating Canonical Religious Texts. Traduction, Terminologie, Rédaction, 7(1), 191-217. URL: http://www.bible-researcher.com/nida4.html (accessed: 20.04.2019).

17. Desnitskii, A.S. Eugene Nida: an Appearance of the Bible Translation Theory. URL: http://archive.bogoslov.ru/text/print/1541684.html (accessed: 01.09.2019). (In Russ).

18. An Appeal to Christ-Loving Reader in the $1^{\text {st }}$ Russian Edition of the New Testament. URL: https://www.pravmir.ru/vozglashenie-k-xristolyubivym-chitatelyam-pri-pervom-izdaniievangeliya-na-russkom-narechii/_accessed: 22.08.2019). (In Russ). 
19. Khukhuni, G.T. \& Osipova, A.A. (2019). "Holy Kiss", or "Hearty Handshake"? (about the Limits of Pragmatic Adaptation in Translation), Military-Humanitarian Almanac, 4(2), 8 18. (In Russ).

20. Translating the Gospels. A Discussion Between Dr. E.V. Rieu and the Rev. J.B. Phillips. (1955). The Bible Translator 6/4. October. pp. 150-159.

21. Marlowe, Michael. (2012). Against the Dynamic Equivalence Theory. Revised and Expanded in 2012. URL: http://www.bible-researcher.com/dynamic-equivalence.html (accessed: 02.09.2019).

22. C.S. Lewis' introduction to J.B. Phillips'N.T (2018). Epistle of Dude. November, 17. URL: https://epistleofdude.wordpress.com/2018/11/17/c-s-lewis-introduction-to-j-b-phillips-nt/_(accessed: 08.09.2019).

23. Reiß, K. \& Vermeer, H.J. (1984). Grundlegung einer allgemeinen Translationstheorie (Linguistische Arbeiten 147). Tübingen: Niemeyer.

24. Version Information. Bible Gateway. URL: https://www.biblegateway.com/versions/newinternational-version-niv-bible (accessed: 08.09.2019).

25. Sharov, K.S. (2019). Gender-Neutral Linguistic Transformations of Messianic Scriptures in the Modern Anglican Homiletic Literature, Russian Journal of Linguistics, 23(2), 523-543. (In Russ). Doi: 10.22363/2312-9182-2019-23-2-523-543.

26. Chukovskii, K.I. (2008). The High Art. The Principles of Literary Translation. Saint Petersburg: Publishing House "Akvalon". Publishing House "Alphabet Classic". (In Russ).

27. Ivanov, A.I. (1954). New Russian Translaation of Matthew (the End), Journal of Moscow Patriarchy, 5, May. URL: http://archive.e-vestnik.ru/page/index/195405369.html (accessed: 08.09.2019). (In Russ).

28. Prozorovskii, D.I. Versta. ESBE. URL: https://ru.wikisource.org/wiki/\%D0\%AD\%D0\%A1\% D0\%91\%D0\%95/\%D0\%92\%D0\%B5\%D1\%80\%D1\%81\%D1\%82\%D0\%B0 (accessed: 25.03.2018). (In Russ).

\section{Sources}

29. Good News Translation. Bible Gateway. URL: https://www.biblegateway.com/passage/ ?search $=2+$ Corinthians+13\&version=GNT. (accessed: 02.09.2019).

30. Gute Nachricht Bibel. Bible Gateway. URL: https://www.die-bibel.de/bibeln/online-bibeln/gutenachricht-bibel/bibeltext/bibel/text/lesen/stelle/57/10001/19999/ (accessed: 02.09.2019).

31. Holy Bible. New International Version. NIV (2011). Grand Rapid, Michigan: Zondervan. VII.

32. Hoffnung für alle. Die Bibel. (2003). Basel und Gieseß. XXXII.

33. Bible. Modern Russian translation. (2015). Moscow: Russian Bible Society. (In Russ).

34. Bible. The Books of the Holy Writ. Old and New Testament in Modern Russian Translation. (2015). M.P. Kulakov and M.M. Kulakov (Eds.). Moscow: The Publishing House of St. Andrew Biblical Theological Institute. (In Russ).

35. Holy Writ. Central Asian Translation. Bible Gateway. URL: https://www.biblegateway.com/versions/ $\% \mathrm{D} 0 \% \mathrm{~A} 1 \% \mathrm{D} 0 \% \mathrm{~B} 2 \% \mathrm{D} 1 \% 8 \mathrm{~F} \% \mathrm{D} 1 \% 89 \% \mathrm{D} 0 \% \mathrm{~B} 5 \% \mathrm{D} 0 \% \mathrm{BD} \% \mathrm{D} 0 \% \mathrm{BD} \% \mathrm{D} 0 \% \mathrm{BE} \% \mathrm{D} 0 \% \mathrm{~B} 5-$ $\% \mathrm{D} 0 \% 9 \mathrm{~F} \% \mathrm{D} 0 \% \mathrm{~B} 8 \% \mathrm{D} 1 \% 81 \% \mathrm{D} 0 \% \mathrm{~B} 0 \% \mathrm{D} 0 \% \mathrm{BD} \% \mathrm{D} 0 \% \mathrm{~B} 8 \% \mathrm{D} 0 \% \mathrm{~B} 5-\% \mathrm{D} 0 \% 92 \% \mathrm{D} 0 \% \mathrm{BE} \% \mathrm{D} 1 \%$ 81\%D1\%82\%D0\%BE\%D1\%87\%D0\%BD\%D1\%8B\%D0\%B9-\%D0\%9F\%D0\%B5\%D1\%80\% D0\%B5\%D0\%B2\%D0\%BE\%D0\%B4-CARS/\#booklist (accessed: 05.09.2019). (In Russ).

36. New Testament. Translated from the Greek Original by Bishop_Kassian (Bezobrazov). Russian Bible Society. URL: http://apologia.hop.ru/bible/kassian/kassian.html (accessed: 24.03.2018). (In Russ).

37. The New Testament of Our Lord Jesus Christ. (1822). Second Edition. Russian Bible Society. Saint Petersburg: Printing House of Russian Bible Society. VIII. (In Russ).

\section{Библиографический список}

1. Nida Eugene A. Toward a Science of Translation. Leiden: Brill, 1964.

2. Nida Eugene A., Taber Ch.R. The Theory and Practice of Translating. Leiden: Brill, 1982. 
3. Waard Jean, Nida E.A. From One Language to Another: Functional Equivalence in Bible Translation. Thomas Nelson Inc., 1986.

4. Bickman John., Callow John. Translating the Word of God: With Scripture and Topical Indexes. Zondervan, 1974.

5. Metzger Bruce M. Persistent Problems Confronting Bible Translators // Bibliotheca Sacra 150 (July-September 1993). 1993. P. 273-284.

6. Chatzitheodorou Ilias. Problems of Bible Translation // Translation Journal. October 2001. Vol. 5 no. 4. Режим доступа: https://www.translationjournal.net/journal/18bible.htm (дата обращения: 08.12.2018).

7. Huaizhou Mao. Commentary on Nida vs. Chomsky's Translation Theories // Theory and Practice in Language Studies, Vol. 2, no. 6. June 2012. P. 1285-1290.

8. Десниикий А.С. Современный библейский перевод. Теория и методология. М.: Издательство ПСТГУ, 2015.

9. Снигирев Р. Национальные Библии и проблема исправления Синодального перевода // Богослов.ру. Научный богословский портал. 23.05.2009. Электронный ресурс. Режим доступа: http://www.bogoslov.ru/text/404972.html (дата обращения: 08.06.2017).

10. Venuti Lawrence M. The Scandals of Translation: Towards an Ethics of Difference. Routledge, 1999.

11. Venuti Lawrence M. Strategies of Translation // Routledge Encyclopedia of Translation Studies. London \& New-York: Routledge. 2001. P. 240-244.

12. Виноградов В.С. Введение в переводоведение (общие и лексические вопросы). М.: Издательство Института общего среднего образования РАО. 2001.

13. Фролов Э.Д. История эллинизма в биографиях его творцов // Бенгтсон Г. Правители эпохи эллинизма. М.: Наука, 1982. С. 3-26.

14. Комиссаров В.Н. Современное переводоведение. Курс лекций. М.: Издательство ЭТС, 2000.

15. Левин Ю.Д. Русские переводчики XIX в. и развитие художественного перевода. Л.: Наука. 1985.

16. Nida E.A. The Sociolinguistics of Translating Canonical Religious Texts // Traduction, Terminologie, Rédaction. 1994. vol. 7. no. 1. P. 191-217. Режим доступа: http://www.bibleresearcher.com/nida4.html (дата обращения: 20.04.2019).

17. Возглашение к христолюбивым читателям при первом издании Евангелия на Русском наречии. Электронный ресурс. Режим доступа: https://www.pravmir.ru/vozglashenie-kxristolyubivym-chitatelyam-pri-pervom-izdanii-evangeliya-na-russkom-narechii/. (дата обращения: 01.09.2019).

18. Десницкий А.С. Юджин Найда: рождение теории библейского перевода. Электронный peсурс. Режим доступа: http://archive.bogoslov.ru/text/print/1541684.html. (дата обращения: 01.09.2019).

19. Хухуни Г.Т., Осипова А.А. «Святое целование» или «сердечное рукопожатие» (о границах прагматической адаптации переводного текста // Военно-гуманитарный альманах. 2019. vol. 74. no. 2. C. $8-18$.

20. Translating the Gospels. A Discussion Between Dr. E.V. Rieu and the Rev. J.B. Phillips // The Bible Translator 6/4. October, 1955. P. 150-159.

21. Marlowe M. Against the Dynamic Equivalence Theory. Revised and Expanded in 2012. Электронный ресурс. Режим доступа: http://www.bible-researcher.com/dynamicequivalence.html. (дата обращения: 02.09.2019).

22. C.S. Lewis' introduction to J.B. Phillips'N.T // Epistle of Dude. November 17. 2018. Электронный ресурс. Режим доступа: https://epistleofdude.wordpress.com/2018/11/17/c-slewis-introduction-to-j-b-phillips-nt/. (дата обращения: 20.04.2019).

23. Reiß K., Vermeer, H. J. Grundlegung einer allgemeinen Translationstheorie (Linguistische Arbeiten 147). Tübingen: Niemeyer, 1984. 
24. Version Information // Bible Gateway. Электронный pecypc. Режим доступа: https://www.biblegateway.com/versions/new-international-version-niv-bible (дата обращения: 03.09.2019).

25. Шаров К.С. Гендерно-нейтральные лингвистические трансформации мессианских священных текстов в современной англиканской гомилетической литературе // Russian Journal of Linguistics. 2019. vol. 23. no. 2. C. 523 - 543. Doi: 10.22363/2312-9182-2019-232-523-543.

26. Чуковский К.И. Высокое искусство. Принципы художественного перевода. СПб.: ИД «Аквалонъ», Издательский дом «Азбука-классика», 2008.

27. Иванов А. Новый перевод на русский язык Евангелия от Матфея (окончание) // Журнал Московской патриархии. май, 1954. № 05. Электронный ресурс. Режим доступа: http://archive.e-vestnik.ru/page/index/195405369.html. (дата обращения: 24.03.2018).

28. Прозоровский Д.И. Верста // ЭСБЕ. Электронный ресурс. Режим доступа: https://ru.wikisource.org/wiki/\%D0\%AD\%D0\%A1\%D0\%91\%D0\%95/\%D0\%92\%D0\%B5\% $\mathrm{D} 1 \% 80 \% \mathrm{D} 1 \% 81 \% \mathrm{D} 1 \% 82 \% \mathrm{D} 0 \% \mathrm{~B} 0$. (дата обращения: 25.03.2018).

\section{Источники}

29. Good News Translation // Bible Gateway. Электронный ресурс. Режим доступа: https://www.biblegateway.com/passage/?search=2+Corinthians+13\&version=GNT. (дата обращения: 02.09.2019).

30. Gute Nachricht Bibel. Bible Gateway. Электронный ресурс. URL // Режим доступа: https://www.die-bibel.de/bibeln/online-bibeln/gute-nachricht-

bibel/bibeltext/bibel/text/lesen/stelle/57/10001/19999/. Дата обращения 02.09.2019

31. Holy Bible. New International Version / NIV Grand Rapid, Michigan: Zondervan. VII. 2011.

32. Hoffnung für alle. Die Bibel Basel und Gieseß. XXXII. 2003.

33. Библия. Современный русский перевод. М.: Российское библейское общество. 2015.

34. Библия. Книги Священного Писания Ветхого и Нового Завета в современном русском переводе. Под ред. М.П. Кулакова и М.М. Кулакова. М.: Издательство ББИ. 2015.

35. Священное Писание. Восточный перевод. Bible Gateway. Электронный ресурс // Режим доступа: https://www.biblegateway.com/versions/\%D0\%A1\%D0\%B2\%D1\%8F\%D1\%89\%D0\%B5\%D0\%BD $\% \mathrm{D} 0 \% \mathrm{BD} \% \mathrm{D} 0 \% \mathrm{BE} \% \mathrm{D} 0 \% \mathrm{~B} 5-\% \mathrm{D} 0 \% 9 \mathrm{~F} \% \mathrm{D} 0 \% \mathrm{~B} 8 \% \mathrm{D} 1 \% 81 \% \mathrm{D} 0 \% \mathrm{~B} 0 \% \mathrm{D} 0 \% \mathrm{BD} \% \mathrm{D} 0 \% \mathrm{~B} 8 \%$ D0\%B5-\%D0\%92\%D0\%BE\%D1\%81\%D1\%82\%D0\%BE\%D1\%87\%D0\%BD\%D1\%8B\%D0\%B9$\% \mathrm{D} 0 \% 9 \mathrm{~F} \% \mathrm{D} 0 \% \mathrm{~B} 5 \% \mathrm{D} 1 \% 80 \% \mathrm{D} 0 \% \mathrm{~B} 5 \% \mathrm{D} 0 \% \mathrm{~B} 2 \% \mathrm{D} 0 \% \mathrm{BE} \% \mathrm{D} 0 \% \mathrm{~B} 4-\mathrm{CARS} /$ \#booklist. (дата обращения: 05.09.2019).

36. Новый Завет. Перевод с греческого подлинника епископа Кассиана (Безобразов) // Российское Библейское Общество. Электронный ресурс. Режим доступа: http://apologia.hop.ru/bible/kassian/kassian.html. (дата обращения: 24.03.2018).

37. Господа нашего Новый Завет на славянском и русском языке. Иждивением Российского Библейского общества. Вторым тиснением. Санкт-Петербург: В Типографии Российского Библейского Общества. VIII. 1822.

\section{Сведения об авторах:}

Хухуни Георгий Теймуразович, доктор филологических наук, профессор, заведующий кафедрой теории языка и англистики ГОУ ВО МО Московского государственного областного университета; сфера научных интересов: теория и история перевода, история языкознания, теория языка, сопоставительное языкознание, социолингвистика, психолингвистика; e-mail: khukhuni@mail.ru

Валуйщева Ирина Ивановна, доктор филологических наук, профессор, заведующий кафедрой теоретической и прикладной лингвистики ГОУ ВО МО Московского государственного областного университета; сфера научных интересов: теория перевода, теория языка, сопоставительное языкознание, социолингвистика, психолингвистика; e-mail: irinaiv-v@yandex.ru 
Осипова Анна Александровна, доктор филологических наук, профессор кафедры теории и практики перевода и коммуникации ФГБОУ Московского педагогического государственного университета; сфера научных интересов: теория и история перевода, сопоставительное языкознание, преподавание русского языка как иностранного; e-mail: assya@yandex.ru

\section{Information about the authors:}

Georgy T. Khukhuni, DSc. in Philology, Full Professor, Head of the Department of the Theory of Language and English Studies Moscow Region State University. The sphere of research includes Theory and History of Translation, History of Linguistics, Theory of Language. Comparative Linguistics, Sociolinguistics, Psycholinguistics; e-mail: khukhuni@mail.ru

Irina I. Valuitseva, DSc. in Philology, Full Professor, Head of the Department of the Theoretical and Applied Linguistics Moscow Region State University. The sphere of research includes Theory of Translation, Theory of Language. Comparative Linguistics, Sociolinguistics, Psycholinguistics; e-mail: irinaiv-v@yandex.ru

Anna A. Osipova, DSc. in Philology, Full Professor of the Department Translation and Communication of Moscow Pedagogical State University. The sphere of research includes Theory and History of Translation, Comparative Linguistics, Teaching Russian as foreign Language; e-mail: assya@yandex.ru 